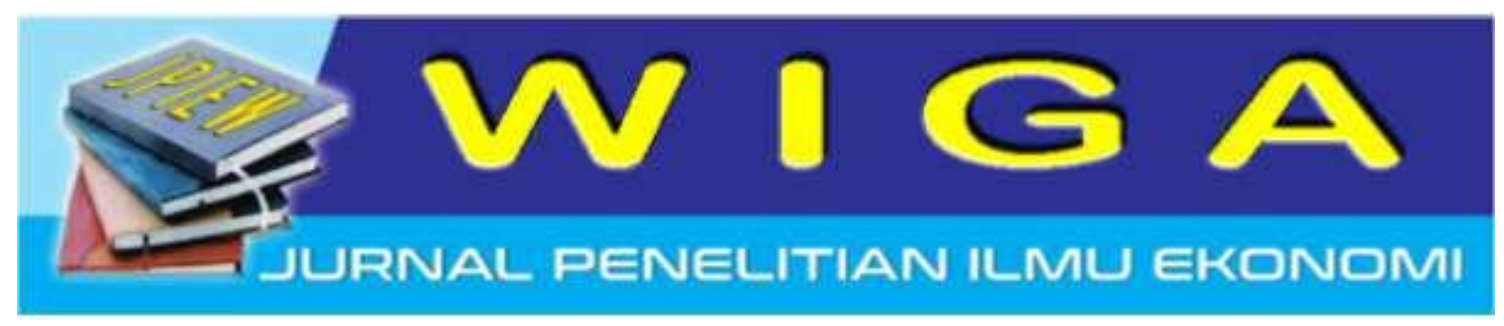

\title{
Determinan Harga Saham Perusahaan Yang Terdaftar Di Bursa Efek Indonesia
}

\author{
Sukma Irdiana \\ STIE Widya Gama Lumajang \\ irdiana_pasah77@yahoo.com
}

\begin{abstract}
ABSTRAK
Pasar modal adalah salah satu bentuk pasar keuangan, dimana para pelaku pasar modal melakukan investasi dalam bentuk surat berharga yang ditawarkan oleh emiten. Salah satu surat berharga yang paling populer untuk diperjualbelikan di pasar modal adalah saham. Saham merupakan surat berharga yang memiliki keuntungan dan resiko yang tinggi atau yang lebih dikenal dengan high risk and high return. High risk and high return adalah semakin tinggi resiko dari sebuah investasi maka semakin tinggi pula jumlah keuntungan yang diperoleh dari sebuah investasi tersebut. Tujuan penelitian ini adalah untuk memperoleh bukti secara empiris dan menemukan kejelasan tentang pengaruh variable fundamental yang terdiri dari ROA, EPS, NPM, DER dan BVS terhadap harga saham perusahaan yang terdaftar di BEI periode 2010-2015, baik secara parsial maupun simultan. Metode pemilihan sampel yang digunakan adalah purposive sampling dan model analisis yang digunakan adalah analisis regresi linier berganda. Hasil penelitian menunjukkan bahwa secara parsial ROA, EPS, NPM, DER, dan BVS berpengaruh secara signifikan terhadap harga saham. Secara simultan ROA, ROE, EPS, NPM, DER dan BVS secara serentak berpengaruh terhadap harga saham. Koefisien Determinasi (R Square) sebesar 48\% dan sisanya sebesar 52\% dipengaruhi oleh variabel lain yang belum diteliti dalam penelitian ini.
\end{abstract}

Kata kunci : ROA, EPS, NPM, DER, dan BVS

\begin{abstract}
Capital market is one form of financial market, where the capital market players invest in the form of securities offered by the issuer. One of the most popular securities for sale on the stock market is stock. Stocks are securities that have high profits and risks or better known as high risk and high return. High risk and high return is the higher the risk of an investment, the higher the amount of profits derived from an investment. The purpose of this study is to obtain evidence empirically and find clarity about the influence of fundamental variables consisting of ROA, EPS, NPM, DER and BVS to stock prices of companies listed in IDX period 2010-2015, either partially or simultaneously. Sample selection method used is purposive sampling and analysis model used is multiple linier regression analysis. The results showed that partially ROA, EPS, NPM, DER, and BVS have a significant effect on stock prices. Simultaneously ROA, ROE, EPS, NPM, DER and BVS simultaneously affect the
\end{abstract}


stock price. Coefficient of Determination (R Square) of $48 \%$ and the rest of $52 \%$ influenced by other variables that have not been studied in this study.

Keywords: ROA, EPS, NPM, DER, and BVS

\section{PENDAHULUAN}

Pasar modal adalah pasar keuangan yang memperjualbelikan surat berharga untuk jangka panjang yang dilakukan di bursa efek. Menurut Tandelilin (2001:18), saham adalah surat berharga yang dapat di perjualbelikan di pasar modal. Saham merupakan surat berharga yang mengacu pada kepemilikan terhadap sebuah perusahaan. Dalam saham keuntungan dan resiko yang tinggi sering dikenal dengan high risk and high return. High risk and high return adalah semakin tinggi resiko dari sebuah investasi maka semakin tinggi pula jumlah keuntungan yang diperoleh dari sebuah investasi tersebut (Manurung, 2003:98).

Untuk melakukan investasi di pasar modal diperlukan suatu analisis untuk mengukur nilai saham. Alat ukur yang sering digunakan adalah analisis fundamental dan analisis teknikal. Analisis fundamental digunakan untuk mengukur apakah nilai saham berada pada posisi undervalue atau overvalue. Dikatakan undervalue apabila harga saham di pasar saham lebih kecil daripada harga wajar yang seharusnya, demikian pula sebaliknya (Anastasia, 2000).

Analisis fundamental lebih memusatkan pada laporan keuangan dengan tujuan untuk mendeteksi perbedaan harga saham dengan nilai intrinsik. Nilai intrinsik dapat diketahui melalui laba, dividen, struktur modal, ratio dan potensi pertumbuhan perusahaan. Faktor fundamental yang sering digunakan dalam memprediksi harga saham adalah rasio keuangan dan rasio pasar. Rasio keuangan yang sering digunakan sebagai proksi harga saham adalah ROA (Return On Asset), DER (Debt Equity Ratio), ROE (Return On Equity), BVS (Book Value Per Share). Rasio-rasio diatas digunakan untuk menilai tingkat kewajaran harga saham.
Untuk mengukur faktor-faktor yang mempengaruhi harga saham, peneliti menggunakan variable diantaranya ROA (Return On Asset), DER (Debt Equity Ratio), BVS (Book Value Per Share), EPS (Earning Per Share) dan NPM (Net Profit Margin). Alasan peneliti mengambil penelitian ini karena peneliti ingin melihat dari sudut pandang para investor dalam mengambil suatu keputusan investasi di pasar modal, khususnya di Bursa Efek Indonesia.

Dalam penelitian ini, peneliti mengambil saham Blue Chips. Karena saham Blue Chips adalah saham yang mewakili ciri-ciri sebagai berikut yaitu pertama perusahaan besar, yang memiliki reputasi baik serta dikenal oleh masyarakat. Kedua memiliki kinerja / fundamental yang bagus, dan biasanya merupakan pemimpin di industri/sektornya masing-masing. Ketiga saham likuid.

Berdasarkan latar belakang diatas maka perumusan masalah penelitian ini adalah Apakah Return On Assets (ROA), Net Profit Margin (NPM), Earning Per Share (EPS), Book Value Per Share (BVS) dan Debt to Equity Ratio (DER) terdapat pengaruh secara parsial terhadap harga saham pada perusahaan yang terdaftar di Bursa Efek Indonesia?. Dan Apakah Return On Assets (ROA), Net Profit Margin (NPM), Earning Per Share (EPS), Book Value Per Share (BVS) dan Debt to Equity Ratio (DER) terdapat pengaruh secara simultan terhadap harga saham pada perusahaan yang terdaftar di Bursa Efek Indonesia?.

Tujuan penelitian ini adalah untuk mengetahui Return On Assets (ROA), Net Profit Margin (NPM), Earning Per Share (EPS), Book Value Per Share (BVS) dan Debt to Equity Ratio (DER) berpengaruh secara parsial terhadap harga saham pada perusahaan yang terdaftar di Bursa Efek 
Indonesia. Dan untuk mengetahui Return On Assets (ROA), Net Profit Margin (NPM), Earning Per Share (EPS), Book Value Per Share (BVS) dan Debt to Equity Ratio (DER) berpengaruh secara simultan terhadap harga saham pada perusahaan yang terdaftar di Bursa Efek Indonesia.

\section{TINJAUAN PUSTAKA \\ Harga Saham}

Menurut Widoatmodjo (2000:13), harga saham dapat dibedakan sebagai berikut harga nomina, harga perdana dan harga pasar. Harga nominal merupakan harga yang tertertuang dalam surat berharga yang ditetapkan oleh perusahaan untuk menilai setiap lembar surat berharga yang dikeluarkan. Besar kecilnya harga nominal memberikan asumsi penting dalam surat berharga. Hal ini dikarenakan besar kecilnya deviden, biasanya ditetapkan berdasarkan nilai nominal. Harga perdana merupakan harga pada saat harga saham tersebut tercatat di bursa efek. Harga saham pada pasar perdana biasanya telah ditetapkan oleh para penjamin emisi dan emiten. Untuk mengetahui seberapa besar harga saham akan dijual kepada masyarakat di pasar perdana. Harga pasar merupakan harga jual yang terbentuk oleh investor satu dengan investor yang yang lain. Harga pasar terbentuk setelah saham tercatat di bursa efek. Harga pasar sekunder adalah harga yang tidak lagi melibatkan emiten dari penjamin emisi. Harga ini merupakan perwakilan dari harga perusahaan penerbitnya, karena harga pada pasar sekunder jarang sekali terjadi negosiasi harga antar investor dengan perusahaan penerbit. Harga yang setiap hari diumumkan baik itu di surat kabar maupun media lain merupakan harga pasar.

Dari keterangan diatas maka dapat disimpulkan bahwa harga saham terbentuk di pasar jual beli saham karena akibat dari transaksi jual beli yang terjadi antara investor tersebut dan jika harga pasar saham ditutup maka harga pasar disebut sebagai harga penutupan (closing price) dan jika harga pasar ini dikalikan dengan jumlah saham yang beredar (outstanding share), maka akan didapatkan nilai pasar (market value). Akan tetapi investor juga perlu mengetahui dan memahami harga nominal, harga perdana, dan harga pasar dalam pengambilan keputusan investasi saham karena akan membantu investor untuk mengetahui saham mana yang berkembang dan murah.

\section{Pendekatan Penilaian Harga Saham}

Investor dalam melakukan keputusan investasi di pasar modal memerlukan informasi tentang penilaian saham. Analisis saham bertujuan untuk memperkirakan nilai intrinsik (intrinsic value) suatu saham dan membandingkan dengan harga pasar saham pada saat ini (current market price). Nilai intrinsik suatu saham menunjukkan present value suatu arus kas yang diharapkan dari saham tersebut.

Menurut Halim (2005:5), ada 2 (dua) pendekatan penilaian saham yang dapat digunakan, yaitu a) Pendekatan Fundamental, Pendekatan ini didasarkan pada informasi-informasi yang diterbitkan oleh emiten maupun oleh administrasi bursa efek. Karena kinerja perusahaan dipengaruhi oleh kondisi sektor industri dimana perusahaan berada pada perekonomian makro, maka untuk memperkirakan prospek harga saham dimasa yang datang harus dikaitkan dengan faktor-faktor fundamental yang mempengaruhinya. Sehingga analisis ini dimulai dari siklus usaha perusahaan secara umum dan kemudian ke sektor industri yang berakhir pada evaluasi terhadap kinerja saham yang diterbitkan. b) Pendekatan Teknikal adalah pendekatan yang didasarkan pada data harga saham masa lalu sebagai upaya untuk memperkirakan harga saham di masa mendatang. Dalam pendekatan ini harga saham tergantung pada permintaan dan penawaran saham itu sendiri.

Menurut Anoraga (2006:108), teknik analisis investasi yang paling banyak digunakan, yaitu a) Analisis Fundamental, 
yaitu analisis yang berhubungan dengan kondisi keuangan perusahaan yang menyangkut data-data historis perusahaan. Karena umumnya harga saham sangat bergantung pada kinerja perusahaan yang bersangkutan. b) Analisis Teknikal, yaitu analisis yang menggunakan data-data yang dikumpulkan dari waktu ke waktu dengan mengabaikan hal-hal yang berkaitan dengan posisi keuangan perusahaan. c) Analisis Ekonomi, yaitu analisis yang menggunakan berbagai indikator yang berkaitan dengan kondisi perekonomian, seperti pengenaan pajak, tingkat kesejahteraan masyarakat dan variabel ekonomi lainnya. d) Analisis Rasio Keuangan, yaitu analisis yang didasarkan pada hubungan antar pos dalam laporan keuangan perusahaan yang akan mencerminkan keadaan keuangan serta hasil dari operasional perusahaan.

Berdasarkan penjelasan diatas maka dapat disimpulkan bahwa penilaian ini hanya tertuju pada pendekatan fundamental perusahaan. Karena pendekatan fundamental secara terperinci lebih memfokuskan pada laporan keuangan perusahaan yang tujuannya untuk mengetahui perbedaan harga pasar sekuritas dengan nilai intrinsiknya. Apabila seseorang investor telah melakukan penilaian harga saham berdasarkan fundamentalnya, maka hal itu berarti investor tersebut telah menentukan keputusan untuk membeli dan atau menjual sahamnya dengan baik. Sebab tanpa melalui nilai - nilai fundamental perusahaan, seseorang akan terjebak dalam kegiatan spekulasi perdagangan saham yang hanya mengandalkan keberuntungan yang tidak pasti. Meskipun dalam pendekatan secara fundamental membutuhkan waktu yang cukup lama dalam memprediksikan suatu perusahaan tetapi hasilnya akan berdampak pada prospek perusahaan dalam jangka waktu yang panjang karena nilai fundamental mencerminkan nilai perusahaan yang sebenarnya.

\section{Faktor-Faktor yang Mempengaruhi Harga Saham}

Menurut Harjito (2009: 85), naik turunnya harga saham dipengaruhi oleh beberapa faktor, baik faktor internal maupun eksternal perusahaan. Faktor internal lebih banyak dipengaruhi oleh kondisi fundamental perusahaan, sedangkan faktor eksternal sebagian disebabkan oleh informasi yang diperoleh pasar.

Dari faktor-faktor yang mempengaruhi harga saham, dalam penelitian ini hanya difokuskan pada faktor internal perusahaan. Dimana faktor internal merupakan fundamental perusahaan yang menganalisa kinerja dan kondisi keuangan dan ekonomi perusahaan yang menerbitkan saham tersebut dan menjadi pertimbangan utama dalam menanamkan investasi saham. Sedangkan faktor eksternal merupakan faktor yang mempengaruhi aktivitas pasar modal yang berasal dari kinerja ekonomi secara agregat, seperti tingkat suku bunga, hukum permintaan dan penawaran, news dan rumors, indeks harga saham, valuta asing, dan sebagainya.

\section{Faktor-Faktor Fundamental Perusahaan}

Menurut Arifin (2004: 116), "Faktor fundamental adalah faktor-faktor yang mencerminkan kinerja emiten yang dapat dilihat dari laporan keuangan emiten tersebut". Semakin baik kinerja emiten maka semakin besar pula pengaruhnya terhadap kenaikan harga saham dan demikian sebaliknya, apabila semakin buruknya kinerja emiten maka semakin turunnya harga saham yang diterbitkan dan diperdagangkan pada perusahaan tersebut. Karena kinerja emiten menggambarkan kemampuan perusahaan dalam menghasilkan laba sehingga hal tersebut dapat menumbuhkan kepercayaan investor dalam menanamkan modalnya.

Sehingga dapat dijelaskan bahwa faktor-faktor fundamental perusahaan mencerminkan kinerja suatu emiten, tentang efektifitas dan efisiensi perusahaan 
dalam mencapai sasarannya dimana hal tersebut dapat terlihat dari laporan keuangan suatu perusahaan yang diterbitkan atau dipublikasikan setiap per triwulan, per kuartal, per semester dan per tahun (akhir periode).

Dalam sub bab selanjutnya, penelitian ini akan menjelaskan faktorfaktor fundamental perusahaan yang hanya mencakup ruang lingkup laporan keuangan saja yang digunakan untuk menganalisis harga saham, yaitu diwakili oleh : Return On Assset (ROA), Net Profit Margin (NPM), Earning Per Share (EPS), Book Value Per Share (BVS), dan Debt To Equity Ratio (DER), sebagai berikut :

Return On Assset (ROA) merupakan rasio yang menunjukkan seberapa besar kontribusi asset dalam menciptakan laba bersih. Dengan kata lain, rasio ini digunakan untuk mengukur seberapa besar jumlah laba bersih yang akan dihasilkan dari setiap rupiah dana yang tertanam dalam total asset. Rasio ini dihitung dengan membagi laba bersih terhadap total asset.

Net Profit Margin (NPM) merupakan rasio yang digunakan untuk mengukur besarnya persentase laba bersih atas penjualan bersih. Rasio ini dihitung dengan membagi laba bersih terhadap penjualan bersih. Laba bersih sendiri dihitung sebagai hasil pengurangan antara laba sebelum pajak penghasilan dengan beban pajak penghasilan. Yang dimaksud dengan laba sebelum pajak penghasilan disini adalah laba operasional ditambah pendapatan dan keuntungan lain-lain, lalu dikurangi dengan beban dan kerugian lain-lain.

Earning Per Share (EPS) adalah jumlah laba yang menjadi hak untuk setiap pemegang satu lembar saham biasa. EPS yang besar menunjukkan kemampuan perusahaan yang lebih besar dalam menghasilkan keuntungan bersih dari setiap lembar saham. Peningkatan EPS menandakan bahwa perusahaan berhasil meningkatkan kemakmuran para investor, dan dari hal tersebut akan mendorong investor untuk menambah jumlah modal yang ditanamkan pada perusahaan. Dan itu akan mengakibatkan kenaikan laba yang pada akhirnya ada kecenderungan kenaikan harga saham, begitu juga sebaliknya.

Book Value Per Share (BVS) adalah rasio yang menunjukkan jumlah stockholdersí equity (modal sendiri) yang berkaitan dengan setiap lembar saham yang beredar. Semakin tinggi rasio nilai buku per lembar saham semakin baik hasil yang diperoleh perusahaan (Fabozzi, 2000).

Debt To Equity Ratio (DER). Rasio utang terhadap modal merupakan rasio yang digunakan untuk mengukur besarnya proposal utang terhadap modal. Rasio ini dihitung sebagai hasil bagi antara total utang dengan modal. Rasio ini berguna untuk mengetahui besarnya perbandingan antara jumlah dana yang disediakan oleh kreditor dengan jumlah dana yang berasal dari pemilik perusahaan. Dengan kata lain, rasio ini berfungsi untuk mengetahui berapa bagian dari setiap rupiah modal yang dijadikan sebagai jaminan utang. Rasio ini memberikan petunjuk umum tentang kelayakan kredit dan risiko keuangan debitur.

\section{HIPOTESIS}

Berdasarkan latar belakang, tujuan penelitian dan tinjauan pustaka maka hipotesis penelitian ini adalah :

H1: Return On Assets (ROA), Net Profit Margin (NPM), Earning Per Share (EPS), Book Value Per Share (BVS) dan Debt to Equity Ratio (DER) terdapat pengaruh secara parsial terhadap harga saham pada perusahaan yang terdaftar di Bursa Efek Indonesia.

H2: Return On Assets (ROA), Net Profit Margin (NPM), Earning Per Share (EPS), Book Value Per Share (BVS) dan Debt to Equity Ratio (DER) terdapat pengaruh secara simultan terhadap harga saham pada perusahaan yang terdaftar di Bursa Efek Indonesia.

\section{METODOLOGI PENELITIAN}




\section{Populasi dan Teknik Sampel}

Populasi dalam penelitian ini adalah seluruh perusahaan-perusahaan yang tergabung dalam kelompok saham BLUE CHIPS yang terdaftar pada Bursa Efek Indonesia dari tahun 2010 sampai dengan tahun 2015 yang memiliki laporan keuangan yang lengkap dan dipublikasikan dalam Indonesian Capital Market Directory (ICMD).

Pemilihan sampel dilakukan berdasarkan metode Purposive Sampling, yaitu pemilihan sampel saham perusahaan selama periode penelitian berdasarkan pertimbangan atau kriteria tertentu. Adapun tujuan dari metode ini untuk mendapatkan sampel yang reprensentatif sesuai dengan kriteria yang telah ditentukan.

\section{Jenis dan Sumber Data}

Data yang digunakan dalam penelitian ini merupakan data sekunder. Data sekunder yang berupa laporan keuangan tahunan dari Indonesia Capital Market Directory dan Indonesia Stock Exchange Statistics.

Data tersebut diolah lebih lanjut untuk memperoleh suatu nilai yang menjadi variabel yang digunakan dalam penelitian ini.

\section{Teknik Pengumpulan Data}

Data yang dikumpulkan dalam penelitian ini dengan menggunakan metode studi pustaka dan metode dokumentasi.

\section{Teknik Analisis Data}

Teknik analisis data dengan menggunakan persamaan Multiple Regression (regresi linier berganda) untuk menganalisis variabel independen terhadap variabel dependen. Model ini dipilih karena penelitian ini dirancang untuk menentukan variable independen yang mempunyai pengaruh terhadap variable dependen. Pada penelitian ini, data diolah menggunakan software komputer yaitu SPSS (Statistical Package for Social Science) versi 16,0.

Dalam penelitian ini variabel independen yang digunakan adalah Return On Assets (ROA) (X1), Net Profit Margin (NPM) (X2), Earning Per Share (EPS) (X3), Book Value Per Share (BVS) (X4) dan Debt to Equity Ratio (DER) (X5). Variabel dependen yang digunakan dalam penelitian ini adalah Harga Saham (Y).

Persamaan regresi linier berganda dalam penelitian ini adalah sebagi berikut:

$$
\begin{gathered}
\mathrm{Y}=\alpha+\beta 1 \mathrm{X} 1+\beta 2 \mathrm{X} 2+\beta 3 \mathrm{X3}+\beta 4 \mathrm{X} 4+ \\
\beta 5 \mathrm{X} 5+e
\end{gathered}
$$

\section{Uji Asumsi Klasik.}

Sebelum melakukan pengujian regresi terlebih dahulu dilakukan pengujian asumsi klasik. Pengujian asumsi klasik yang digunakan yaitu : uji normalitas, multikolineariitas, heteroskedastisitas dan autokorelasi.

\section{Pengujian Hipotesis.}

Metode pengujian terhadap hipotesis yang diajukan dilakukan pengujian secara parsial (Uji t) dan pengujian secara simultan (Uji F) serta analisis koefisien determinasi $\left(\mathrm{R}^{2}\right)$ (Ghozali,2005).

\section{HASIL dan PEMBAHASAN \\ Analisis Regresi Linier Berganda}

Analisis regresi linear berganda (multiple regression) dimaksudkan untuk menguji sejauh apa dan bagaimana pengaruh variabel independen terhadap variabel dependen. Analisis regresi ini akan menghasilkan koefisien regresi yang dilihat dari nilai unstandardized coefficient dan menunjukkan arah hubungan antara variabel independen dan variabel dependen. Hasil analisis regresi berganda dapat dilihat pada tabel 1 berikut ini : 
Tabel 1

Hasil Regresi Linier Berganda

\begin{tabular}{|c|c|c|c|c|c|c|c|c|}
\hline \multicolumn{9}{|c|}{ Coefficients $^{\mathrm{a}}$} \\
\hline \multirow{2}{*}{\multicolumn{2}{|c|}{ Model }} & \multicolumn{2}{|c|}{ Unstandardized Coefficients } & \multirow{2}{*}{$\begin{array}{c}\begin{array}{c}\text { Standardized } \\
\text { Coefficients }\end{array} \\
\text { Beta }\end{array}$} & \multirow[b]{2}{*}{$t$} & \multirow[b]{2}{*}{ Sig. } & \multicolumn{2}{|c|}{ Collinearity Statistics } \\
\hline & & B & Std. Error & & & & Tolerance & VIF \\
\hline 1 & (Constant) & 2771.391 & 2694.776 & & 1.028 & .308 & & \\
\hline & ROA & 293.639 & 121.339 & .264 & 2.420 & .018 & .661 & 1.514 \\
\hline & EPS & 20.765 & 3.087 & .958 & 6.727 & .000 & .389 & 2.574 \\
\hline & NPM & -248.538 & 72.395 & -.377 & -3.433 & .001 & .652 & 1.534 \\
\hline & DER & 303.619 & 66.279 & .649 & 4.581 & .000 & .393 & 2.545 \\
\hline & BVS & -1299.520 & 325.990 & -.513 & -3.986 & .000 & .476 & 2.099 \\
\hline
\end{tabular}

a. Dependent Variable: Harga_Saham

Sumber : Data Diolah SPSS

Dari perhitungan regresi linier berganda dengan menggunakan program SPSS forwindows maka didapat hasil sebagai berikut :

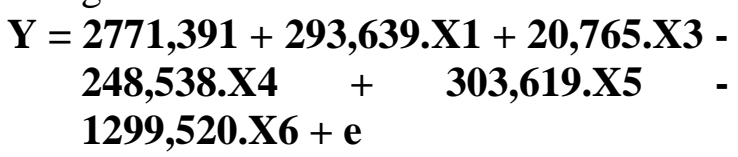

Dari persamaan tersebut diatas dapat dijelaskan :

- Dalam persamaan koefisien regresi diatas, konstanta (Bo) adalah sebesar 2771,391 hal ini berarti jika tidak ada perubahan variabel ROA, EPS, NPM, DER dan BVS tetap sebesar 2771,391.

- Nilai koefisien regresi ROA diperoleh sebesar 293,639. hal ini berarti bahwa apabila ROA naik $1 \%$ maka akan menaikan harga saham sebesar 293,639 atau sebaliknya.

- Nilai koefisien regresi variabel EPS diperoleh sebesar 20,765 hal ini berarti bahwa apabila EPS betambah $1 \%$ maka akan menaikan harga saham sebesar 20,765 atau sebaliknya.

- Nilai koefisien regresi variabel NPM diperoleh sebesar 248,538, hal ini berarti bahwa NPM turun 1\% akan meningkatkan harga saham sebesar 248,538 atau sebaliknya.
- Nilai koefisien regresi variabel DER diperoleh sebesar 303,619 hal ini berarti bahwa apabila DER betambah $1 \%$ maka akan menaikan harga saham sebesar 303,619 atau sebaliknya.

- Nilai koefisien regresi variabel BVS diperoleh sebesar 1299,520, hal ini berarti bahwa BVS turun 1\% akan meningkatkan harga saham sebesar 1299,520 atau sebaliknya.

\section{Hasil Uji Hipotesis \\ Uji t (Uji Parsial)}

Uji ini digunakan untuk menentukkan analisis pengaruh Return On Assets (ROA), Net Profit Margin (NPM), Earning Per Share (EPS), Book Value Per Share (BVS) dan Debt to Equity Ratio (DER) terhadap harga saham pada perusahaan yang termasuk dalam saham Blue Chips yang terdaftar di Bursa Efek Indonesia tahun 2010 - 2015 secara parsial, yang dapat dilihat dari besarnya $\mathrm{t}$ hitung terhadap t tabel dengan uji 2 sisi. Dalam penelitian ini diketahui bahwa $\mathrm{n}=$ 72 pada tingkat signifikan $5 \%$. Pada tingkat kesalahan $(\alpha=0,05)$ dengan menggunakan uji 2 sisi diperoleh nilai $\mathrm{t}$ tabel sebesar 1.99444. Sedangkan t hitung dari variabel Return On Assets (ROA), Net Profit Margin (NPM), Earning Per Share 
(EPS), Book Value Per Share (BVS) dan Debt to Equity Ratio (DER) terhadap harga saham pada perusahaan yang termasuk dalam saham Blue Chips yang terdaftar di Bursa Efek Indonesia tahun 2010-2015 adalah sebagai berikut:

Tabel 2

Hasil Uji t

Coefficients $^{\mathrm{a}}$

\begin{tabular}{|c|c|c|c|c|c|c|c|c|}
\hline \multirow{2}{*}{\multicolumn{2}{|c|}{ Model }} & \multicolumn{2}{|c|}{ Unstandardized Coefficients } & \multirow{2}{*}{$\begin{array}{c}\text { Standardized } \\
\text { Coefficients }\end{array}$} & \multirow[b]{2}{*}{$\mathrm{T}$} & \multirow[b]{2}{*}{ Sig. } & \multicolumn{2}{|c|}{ Collinearity Statistics } \\
\hline & & $B$ & Std. Error & & & & Tolerance & VIF \\
\hline & (Constant) & 2771.391 & 2694.776 & & 1.028 & 308 & & \\
\hline & $\mathrm{ROA}$ & 293.639 & 121.339 & .264 & 2.420 & .018 & 661 & 1.514 \\
\hline & EPS & 20.765 & 3.087 & .958 & 6.727 & .000 & .389 & 2.574 \\
\hline & NPM & -248.538 & 72.395 & -.377 & -3.433 & .001 & 652 & 1.534 \\
\hline & DER & 303.619 & 66.279 & .649 & 4.581 & .000 & .393 & 2.545 \\
\hline & BVS & -1299.520 & 325.990 & -.513 & -3.986 & .000 & 476 & 2.099 \\
\hline
\end{tabular}

a. Dependent Variable: Harga_Saham

Sumber : Data Diolah SPSS

Hasil pada tabel diatas dapat dijelaskan sebagai berikut :

- Untuk variabel ROA nilai t hitung sebesar $2.420>$ nilai t table sebesar 1.99444 dengan tingkat signifikasi lebih dari 0,05 yaitu 0,018. Maka Ho ditolak, jadi variabel ROA berpengaruh signifikan terhadap harga saham.

- Untuk variabel EPS nilai $t$ hitung sebesar 6.727 < nilai t table sebesar 1.99444 dengan tingkat signifikasi lebih dari 0,05 yaitu 0.000. Maka Ho ditolak, jadi variabel EPS berpengaruh signifikan terhadap harga saham.

- Untuk variabel NPM nilai t hitung sebesar -3.433 < nilai t table sebesar 1.99444 dengan tingkat signifikasi lebih dari 0,05 yaitu 0.018. Maka Ho ditolak, jadi variabel NPM berpengaruh signifikan terhadap harga saham.

- Untuk variabel DER nilai t hitung sebesar $4.581>$ nilai $t$ table sebesar 1.99444 dengan tingkat signifikasi lebih dari 0,05 yaitu 0.000. Maka Ho ditolak, jadi variabel DER berpengaruh signifikan terhadap harga saham.

- Untuk variabel BVS nilai t hitung sebesar $-3.986<$ nilai t table sebesar 1.99444 dengan tingkat signifikasi lebih dari 0,05 yaitu 0.000. Maka Ho ditolak, jadi variabel BVS berpengaruh signifikan terhadap harga saham.

\section{Uji F (Uji Simultan)}

Pengujian ini untuk menguji apakah terdapat pengaruh Return On Assets (ROA), Net Profit Margin (NPM), Earning Per Share (EPS), Book Value Per Share (BVS) dan Debt to Equity Ratio (DER) terhadap harga saham pada perusahaan yang termasuk dalam saham Blue Chips yang terdaftar di Bursa Efek Indonesia tahun 2010-2015 secara simultan. Pengujian hipotesis ini dilakukan dengan menggunakan regresi berganda dengan bantuan SPSS. Untuk menguji secara simultan dilakukan analisis masingmasing koefisien regresi. Hasil analisis regresi berganda simultan dapat dilihat pada tabel 3. 
Tabel 3

Hasil Uji F

ANOVA $^{\text {D }}$

\begin{tabular}{|ll|r|r|r|r|r|}
\hline Model & & Sum of Squares & df & Mean Square & F & Sig. \\
\hline 1 & Regression & $3.114 \mathrm{E} 9$ & 5 & $6.229 \mathrm{E} 8$ & 12.192 & $.000^{\mathrm{a}}$ \\
& Residual & $3.372 \mathrm{E} 9$ & 66 & $5.109 \mathrm{E} 7$ & & \\
& Total & $6.486 \mathrm{E} 9$ & 71 & & & \\
\hline
\end{tabular}

a. Predictors: (Constant), BVS, DER, NPM, ROA, EPS

b. Dependent Variable: Harga_Saham

Sumber : Data Diolah SPSS

Untuk menginterprestasikan data diatas kita kembali ke hipotesis yang menyatakan :

Variabel pengaruh Return On Assets (ROA), Net Profit Margin (NPM), Earning Per Share (EPS), Book Value Per Share (BVS) dan Debt to Equity Ratio (DER) terhadap harga saham pada perusahaan yang termasuk dalam saham Blue Chips yang terdaftar di Bursa Efek Indonesia tahun 2010-2015 secara simultan. Dengan tingkat signifikan 5\% dan derajat kebebasan df $1=5$ dan df $2=$ 72 maka didapat Ftabel $=2.35$. Dalam perhitungan diperoleh nilai $\mathrm{F}$ hitung lebih besar dari $\mathrm{F}$ tabel, yaitu $12.192>2.35$ sehingga Ho ditolak. Sedangkan jika dilihat dari nilai sig hitung adalah 0,000

Tabel 4

yaitu $<$ 0,05 maka keputusannya juga menolak Ho yang berarti bahwa secara simultan terdapat pengaruh ROA, EPS, NPM, DER, dan BVS terhadap harga saham pada perusahaan yang termasuk dalam saham Blue Chips yang terdaftar di Bursa Efek Indonesia tahun 2010-2015.

Hasil Koefisien Determinasi (R2)

Koefisien Determinasi

bertujuan untuk mengukur seberapa jauh kemampuan model dalam menerangkan variasi variabel dependen. Nilai koefisien determinasi adalah antara nol dan satu. Nilai R2 yang kecil berarti kemampuan variabel-variabel independen dalam menjelaskan variasi variabel dependen amat terbatas, berikut ini R2 disajikan dibawah ini :

Hasil Koefisien Determinasi (R2)

\begin{tabular}{|l|r|r|r|r|r|}
\hline Model & $\mathrm{R}$ & R Square & $\begin{array}{c}\text { Adjusted R } \\
\text { Square }\end{array}$ & $\begin{array}{c}\text { Std. Error of the } \\
\text { Estimate }\end{array}$ & Durbin-Watson \\
\hline 1 & $.693^{\mathrm{a}}$ & .480 & \multicolumn{4}{|c|}{.441} & 7147.80859 & 2.322 \\
\hline
\end{tabular}
a. Predictors: (Constant), BVS, DER, NPM, ROA, EPS
b. Dependent Variable: Harga_Saham

Sumber : Data Diolah SPSS

Hasil analisis regresi linier berganda tersebut dapat terlihat dari $\mathrm{R}$ Square sebesar 0,480 yang menunjukkan bahwa harga saham dipengaruhi oleh keenam variabel yaitu ROA, EPS, NPM, DER, dan
BVS dan pengaruh sebesar $48 \%$, sisanya yaitu $52 \%(100 \%$ - 48\%) harga saham dipengaruhi variabel lain yang belum diteliti dalam penelitian ini. 
PEMBAHASAN

Pengaruh ROA Terhadap Harga Saham

Penelitian ini membuktikan bahwa Return On Aset (ROA) mempengaruhi harga saham yang akan datang. Nilai thitung adalah 2.420 dengan tingkat signifikansi sebesar 0,018. Nilai t-hitung yang tinggi ini menunjukkan bahwa ROA berpengaruh terhadap harga saham yang akan datang. Dengan tingkat signifikansi tersebut maka dapat disimpulkan bahwa variabel return on asset berpengaruh terhadap harga saham dimasa yang akan datang di perusahaan yang tergabung dalam saham Blue Chips.

Hasil pengujian hipotesis menunjukkan bahwa secara parsial variable ROA memiliki pengaruh yang signifikan terhadap harga saham. Hasil ini sesuai dengan teori yang menyatakan bahwa terdapat hubungan pengaruh yang positif dan signifikan antara ROA terhadap harga saham, yaitu semakin besar hasil yang diperoleh asset, akan meningkatkan harga saham. Hasil penelitian ini konsisten dengan penelitian yang dilakukan oleh Achmad Husaini (2012), Fillya Arum Pandansari (2012), yang menyatakan bahwa terdapat pengaruh yang signifikan antara ROA dengan harga saham. Hal ini bisa terjadi apabila pengguna dan pengelola perusahaan dapat mengoptimalkan asset yang dimilikinya. Sehingga dapat menaikkan profitabilitas dan harga saham perusahaan.

\section{Pengaruh EPS Terhadap Harga Saham}

Nilai t hitung dari EPS sebesar 6.727 dengan nilai signifikansi 0,000 yang lebih besar dari tingkat signifikan yang ditetapkan sebelumnya yaitu 0,05 . Hasil pengujian tersebut menunjukkan bahwa secara parsial, variabel EPS memiliki pengaruh yang signifikan terhadap harga saham. Hasil ini sesuai degan teori yang menyatakan bahwa terdapat pengaruh yang positif dan signifikan antara EPS dengan harga saham, yaitu semakin besar laba yang diberikan dalam setiap lembar saham, maka akan semakin besar harga saham.
Hasil ini juga sesuai dengan penelitian yang dilakukan oleh Henny Septiana Amalia (2008), Rowland Bismark Fernando Pasaribu (2008), Dhita Ayudia Wulandari (2009), Achmad Husaini (2010), Mursidah Nurfadillah (2011), Abied Luthfi Safitri (2013), yang menyatakan bahwa terdapat pengaruh yang positif dan signifikan antara EPS dengan harga saham. Hal ini dikarenakan EPS merupakan salah satu rasio profitabilitas yang mencerminkan laba bersih per lembar saham atau EPS, yang menggambarkan kekuatan manajemen dalam mengelola perusahaan. Investor sering memusatkan perhatian kepada EPS yang dibagikan perusahaan sebagai landasan dalam berinvestasi di pasar modal.

\section{Pengaruh NPM Terhadap Harga Saham \\ Nilai t hitung dari Net Profit} mmargin (NPM) sebesar -3.433, dengan nilai signifikansi sebesar 0,001 yang lebih kecil dari tingkat signifikan yang ditetapkan sebelumnya yaitu 0,05 , maka dapat disimpulkan bahwa net profit margin (NPM) memiliki pengaruh negatif yang signifikan terhadap harga saham pada perusahaan yang tergabung ke dalam saham Blue Chips.

Hasil penelitian ini mendukung Wulandari (2012), A. Rizal Qoribulloh (2013), menyatakan bahwa net profit margin (NPM) berpengaruh negatif signifikan terhadap harga saham perusahaan. Penelitian ini tidak dapat membuktikan teori yang menyatakan NPM berpengaruh positif dan signifikan terhadap harga saham. Net profit margin (NPM) merupakan salah satu ukuran yang digunakan dalam memantau profitabilitas perusahaan. NPM memperlihatkan kemampuan perusahaan dalam menghasilkan keuntungan bersih dari setiap penjualan. Dalam penelitian ini NPM memiliki pengaruh negatif tidak signifikan terhadap harga saham. Kondisi demikian dapat disebabkan oleh investor lebih memperhatikan rasio earning per 
share yang memberikan gambaran secara langsung proporsi keuntungan atas setiap lembar saham, dari pada rasio net profit margin yang memberikan informasi besarnya keuntungan atas setiap penjualan. Karena informasi yang didapat dari EPS lebih jelas dalam memperlihatkan potensi keuntungan yang dapat diperoleh investor atas setiap lembar saham perusahaan yang dimiliki.

\section{Pengaruh DER Terhadap Harga Saham}

Nilai t hitung dari DER sebesar 4.581 dengan nilai signifikansi 0,000 yang lebih besar dari tingkat signifikan yang ditetapkan sebelumnya yaitu 0,05 , sehingga artinya hipotesis pada penelitian ini diterima. Jadi terdapat pengaruh yang signifikan antara DER terhadap tingkat harga saham. Artinya semakin tinggi nilai DER maka akan diikuti semakin tinggi tingkat harga saham perusahaan yang bersangkutan. Hasil penelitian ini juga sesuai dengan penelitian yang dilakukan oleh Fillya Arum Pandansari (2012), yang menyatakan bahwa terdapat pengaruh yang positif dan signifikan antara EPS dengan harga saham. Harga saham perusahaan umumnya dapat menjadi tolak ukur atau memonitor perusahaan dalam penelitian ini DER mempengaruhi tingkat harga saham perusahaan yang bersangkutan. Hal ini disebabkan karena tingkat DER tidak berpengaruhi secara langsung sehingga tidak langsung akan semakin meningkatkan harga saham.

DER merupakan pertumbuhan saham perusahaan yang mayoritas dimiliki oleh institusi atau lembaga, seperti: perusahaan asuransi, textile, perusahaan PER, asset management dan pertumbuhan institusi lain (Tarjo, 2008). Pranata dan Mas'ud (2003) menyatakan bahwa monitoring yang dilakukan oleh investor perusahaan tentunya akan menjamin kemakmuran untuk pemegang saham, pengaruh DER sebagai agen pengawas ditekan melalui DER mereka yang cukup besar dalam pasar modal. Tingkat DER yang tinggi akan menimbulkan usaha pengawasan yang lebih besar oleh pihak investor perusahaan sehingga dapat mengurangi perilaku oportunistik manajer dan DER.

\section{Pengaruh BVS Terhadap Harga Saham}

Nilai t hitung dari BVS sebesar 3.986, dengan nilai signifikansi sebesar 0,000 yang lebih besar dari tingkat signifikan yang ditetapkan sebelumnya yaitu 0,05 , maka dapat disimpulkan bahwa BVS memiliki pengaruh negatif yang signifikan terhadap harga saham pada perusahaan yang tergabung ke dalam saham Blue Chips.

Hasil penelitian ini berbeda dengan hasil penelitian sebelumnya, Fillya Arum Pandansari (2012), Erik Mahfud Fathoni (2014), yang menyatakan bahwa memiliki pengaruh yang positif dan signifikan terhadap harga saham. Perbedaan ini dapat disebabkan oleh perbedaan sampel yang diteliti. Hal ini mengidentifikasikan bahwa ketika jumlah equitas dibagi dengan lembar saham yang dibagikan mengalami peningkatan maka nilai buku per lembar saham juga mengalami peningkatan. Setiap peningkatan pada nilai buku per lembar saham, juga berkaitan dengan peningkatan harga saham di pasaran. Semakin besar nilai equitas per lembar saham, maka akan semakin meningkatkan harga saham.

\section{KESIMPULAN DAN SARAN Kesimpulan}

Berdasarkan analisis dan pembahasan hasil penelitian dengan melakukan pengujian hipotesis menggunakan analisi regresi linier berganda, dapat diambil kesimpulan sebagai berikut :

- Secara parsial factor-faktor fundamental yang terdiri dari ROA, NPM, EPS, BVS, dan DER berpengaruh terhadap harga saham. Hal ini menunjukkan bahwa faktorfaktor fundamental perusahaan mencerminkan kinerja suatu emiten, tentang efektifitas dan efisiensi 
perusahaan dalam mencapai sasarannya dimana hal tersebut dapat terlihat dari laporan keuangan suatu perusahaan yang diterbitkan atau dipublikasikan setiap per triwulan, per kuartal, per semester dan per tahun (akhir periode).

- Secara simultan hasil penelitian menunjukkan ada pengaruh yang signifikan antara ROA, ROE, NPM, EPS, BVS, dan DER terhadap harga saham. Sedangkan nilai $\mathrm{R}$ Square sebesar 0.480 atau $48 \%$ menunjukkan bahwa kontribusi pengaruh ROA, ROE, NPM, EPS, BVS, dan DER terhadap harga saham sebesar $48 \%$ dan sisanya sebesar $52 \%$ dipengaruhi oleh variable lain yang tidak dimasukkan dalam penelitian ini.

\section{Saran}

Berkaitan dengan penelitian ini penulis menyarankan beberapa hal sebagai berikut :

- Bagi investor sebelum mengambil keputusan investasi pada saham, sebaiknya perlu memperhatikan informasi-informasi yang diindikasikan mempunyai pengaruh yang signifikan terhadap harga saham. Investor dapat menggunakan ROA, NPM, EPS, BVS, dan DER sebagai pijakan dalam berinvestasi, terutama untuk investasi jangka panjang. Karena ke lima variable ini mempunyai pengaruh yang signifikan terhadap harga saham, khususnya saham-saham yang termasuk kedalam saham Blue Chips. Investor dapat mengestimasi harga suatu saham perusahaan dengan melihat ROA, NPM, EPS, BVS, dan DER.

- Bagi perusahaan, hasil penelitian ini bisa dijadikan dasar untuk pengambilan keputusan. Pihak perusahaan dapat mempertahankan dan meningkatkan nilai EPS yang diberikan agar lebih menarik bagi investor. Perusahaan juga perlu memperhatikan nilai BVS, NPM, DER, dan ROA karena ke empat variable tersebut juga mengindikasikan bahwa jika harga saham tersebut tinggi, berarti saham tersebut memiliki nilai yang lebih besar dari nilai bukunya. Hal ini menandakan perusahaan tersebut memiliki kinerja yang baik, sehingga menrik untuk dijadikan sebagai wadah investasi jangka panjang bagi investor.

- Penelitian ini memiliki keterbatasanketerbatasan yang dapat dijadikan bahan pertimbangan bagi peneliti berikutnya agar mendapatkan hasil yang lebih baik lagi. Keterbatasan dalam penelitian ini hanya meneliti variable ROA, NPM, EPS, BVS, dan DER. Sehingga dalam penelitian selanjutnya dapat memasukkan dalam model penelitian factor-faktor lainnya yang diperkirakan dapat mempengaruhi harga saham. Factor tersebut diantara yaitu factor teknikal seperti volume perdagangan saham. Selain itu juga dapat memasukkan factor makro ekonomi, seperti tingkat inflasi, nilai rupiah terhadap dollar, produk domestic bruto, tingkat suku bunga dan lain-lain. Kemudian juga factor fundamental perusahaan lainnya yang belum diteliti, seperti dividen payout ratio, $\mathrm{PBV}$, PER, pertumbuhan aktiva, likuiditas dan lain-lain. Penelitian selanjutnya juga dapat membandingkan dengan harga saham dari kelompok sector lain yang terdaftar di BEI, dengan menggunakan rentang waktu yang berbeda dan lebih lama agar diperoleh hasil yang lebih akurat, serta melakukan pengembangan teori sehingga penelitian selanjutnya lebih baik dan komprehensif.

\section{Daftar Pustaka}

Adler Haymens Manurung, 2003. Memahami Seluk Beluk Investasi, PT. Adler Manurung, Jakarta. 
Agus Harjito. 2009. Keuangan Perilaku Menganalisis Keputusan Investor. Edisi pertama. EKONISIA. Yogyakarta.

Ali Arifin. 2004. Membaca Saham. Penerbit Andi: Yogyakarta

Anastasia, N., Yanny Widiastuty G., dan Imelda Wijayanti, Analisis Faktor Fundamental dan Risiko Sistematik terhadap Harga Saham Properti di BEJ, Jurnal Akuntansi \& Keuangan Vol. 5 No. 2, November 2003.

Anoraga, Pandji, dan Piji Pakarti. 2006. Pengantar Pasar Modal. PT. Rineka Cipta. Jakarta.

Darmadji, Tjiptono dan Hendy $M$. Fakhruddin. (2006). Pasar Modal di Indoneisa: Pendekatan Tanya Jawab. Ed2. Jakarta: Salemba Empat.

Fabozzi, Frank J. 2000. Manajemen Investasi; Buku Dua; Salemba Empat, Pearson Education Asia Pte. Ltd. Prentice-Hall.

Ghozali, Imam. 2005. Aplikasi Analisis Multivariate Dengan Program SPSS. Semarang: Badan Penerbit Universitas Diponegoro.

Halim, Abdul. 2005. Analisis Investasi. Jakarta: Salemba Empat.

Tandelilin, Eduardus. 2001. Analisis Investasi dan Manajemen Portofolio. Yogyakarta: BPFE-UGM.

Widoatmojo, Sawidji. 2000. Cara Sehat Investasi di Pasar Modal. Jakarta: PT Jurnalida Aksara Grafika. 